\title{
In Vitro Digestibility of Native Grass Hay ${ }^{1}$
}

\section{J. F. KARN, D. C. CLANTON, AND L. R. RITTENHOUSE2}

Technician, Professor, and Graduate Student, Department of Animal Science, University of Nebraska, North Platte Station, North Platte.

\section{Highlight}

Method of storage had a greater effect on the in vitro dry matter digestibility (DMD) of native grass hay than either storage time or date of cutting. The nutritive value of native hay was maintained better by storing it in round bales than by storing it in windrows, bunches or letting it remain standing. The first 60 days in storage was the period when native hay had the greatest loss of nutritive value regardless of storage method. There was an interaction of cutting date and year on DMD. The early cut hay in 1962 had a higher DMD $(42.7 \%)$ than the late cut hay $(40.3 \%)$. There was no difference in 1963 (40.6 vs. 40.1\%).

Native hay is stored in a variety of ways, usually for several months before it is fed. Relatively large quantities of readily soluble nutrients may be lost due to weathering during this storage period. It is possible that the method of storage might have a profound effect on the magnitude of these losses.

Guilbert et al. (1931) obtained losses of 6 to $35 \%$ nitrogen-free extract in hay samples following artificial leaching. Archibald et al. (1951) also found decreases in nitrogen-free extract, carotene and total sugars and an increase in fiber in grass hay as storage time increased. Moxon et al. (1951) found that the crude protein content of standing forage decreased from about 8 to less than $3 \%$ from July 13 to December 7 while the protein content of windrowed hay remained relatively constant during this period.

The botanical and chemical composition of the forage used in the

\footnotetext{
${ }^{1}$ Published with the approval of the Director as Paper No. 2671 Journal Series, Nebraska Agricultural Experiment Station. Received February 20, 1970; accepted for publication September 3, 1970 .

${ }^{2}$ Present address: Squaw Butte Experiment Station, Burns, Oregon.
}

study discussed here were reported by Streeter et al. (1966). The purpose of this investigation was to study the effect that date of cutting, method of storage and storage time had upon the in vitro dry matter digestibility (DMD) of native grass hay.

\section{Methods}

The experimental plots were located on a sands range site in the Sandhills of Central Nebraska. The following methods of storage were imposed upon early (July 13) and late ( $\Lambda$ ugust 27) cutting dates during 1962 and 1963: (1) standing forage; (2) windrowed with a dump rake; (3) bunched with a basket attached to the cutter bar of a tractormounted mowcr; and (4) round baled with a rotobaler. The four methods of storage were replicated three times within each of the two cutting date plots and were randomized within each replication. The forage was sampled immediately after each cutting and at the end of each month thereafter until the end of the storage period in January. The study was conducted using the same plots two different years. The two stage in vitro fermentation procedure of Tilley and Terry (1963) was used to obtain the DMD data. Duplicate determinations were made on each sample with replications on two different days. The data were corrected for dry matter additions to the fermentations via the inoculum. The leastsquares analysis of variance was used to statistically analyze the data because of unequal numbers between the early and late cutting dates.

\section{Results and Discussion}

The relationship of cutting date and storage time on in vitro DMD are presented in Figure 1. All methods of storage are pooled within cutting dates. There was a sharp decline in DMD between July and September for the two cuttings both years. However, there was essentially no change in DMD in either year between September and January. The data for 1963 indicates that there was a much greater decrease in DMD between July and September than in 1962. Although the hays harvested in 1963 had higher initial DMD, by September they had decreased below the DMD for the 1962 hays. This sharp decrease in DMD in 1963 was probably due in part to rainfall pattern. In 1963 there were $12.7 \mathrm{~cm}$ of rainfall prior to the August sampling date and another 12.7 between the August and September sampling dates. In 1962 there were $22.86 \mathrm{~cm}$ of rainfall prior to the August sampling date, but only $3.56 \mathrm{~cm}$ between the August and September sampling dates. A summary of the artificial leaching experiments of Guilbert and Mead as discussed by Watson and Nash (1960) showed that a series of showers with drying conditions between will cause more leaching than one rain regardless of amount and intensity.

In 1962 there was a much greater difference between the DMD of the early and late cut hays than in 1963 (Fig. 1). A significant $(\mathrm{P}<.01)$ year by cutting date interaction showed a greater decline in DMD between early and late cut hay in 1962 (42.7 vs. $10.3 \%$ ) than in 1963 ( 40.6 vs. $40.1 \%$ ). One of the reasons for the wide difference in DMD between the early and late cutting in 1962 was probably related to forage yields. The $22.86 \mathrm{~cm}$ of rain which fell between the early and late cutting dates in 1962 resulted in a yield of $74.5 \mathrm{~kg} /$ ha more forage for the late cut hay than for the early cut hay. As a result, the late cut hay was coarse and more highly lignified than the early cut hay which no doubt contributed to its lower DMD. Kamstra et al. (1958) reported that as plants mature lignin content increases and in vitro cellulose digestion decreases. 


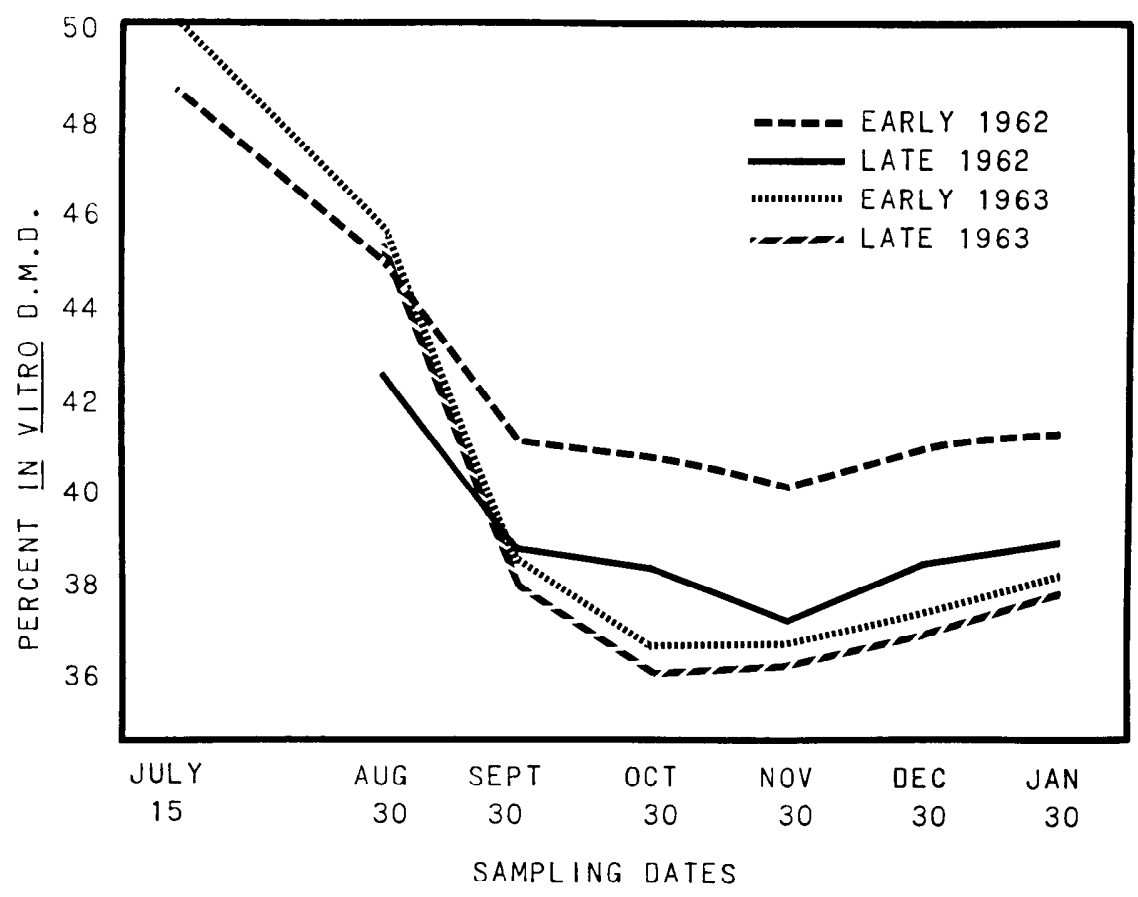

FIr. 1. The relationship of cutting date and storage time on in vitro DMD.

Prichard et al. (1963) found that the most rapid decline in in vitro digestibility begins with head emergence. They also observed that the rate of decline in in vitro digestibility was greater for the heads and stems than for the leaves. In 1963 there were only $18.7 \mathrm{~kg} / \mathrm{ha}$ greater yield from the late cut than from the early cut hay. There was much less forage growth between cuttings in 1963 than in 1962, and, hence, less physical change in the forage which would be reflected in its digestibility.

In vivo apparent energy digestibility values reported by Streeter et al. (1966) on the forages that were baled would tend to substantiate the in vitro DMD differences as related to year and cutting date (Fig. 1). These values were 1.81 and $1.38 \mathrm{megcal} / \mathrm{kg}$ in 1962 and 1.71 and 1.72 megcal $/ \mathrm{kg}$ in 1963 for the early and late cut hays, respectively.

The DMD of the baled hay remained higher $(\mathbf{P}<.01)$ throughout the storage period than the DMD of hay stored by other methods (Fig. 2). However, analysis of these forages for nitrogen, phosphorus and lignin failed to show a consistent nutritional advantage for baled hay as a method of storage (Streeter et al., 1966). There was much less difference between the DMD of baled hay and the DMD of forage stored by the other methods in 1962 than in 1963. In 1962 the DMD for the bunched and windrowed hays declined much less than the standing forage. However, in 1963 there was little difference between the windrowed, bunched and standing forage. It is possible that the greater yield of forage in 1962 might have afforded more protection against weathering for the bunched and windrowed hays and hence, less decline in their DMD was noted. It should also be pointed out that while the DMD of the baled, bunched and windrowed hays for both years declined only until October, the standing forage continued to decline until November or December.

The in vivo DMD values of the 1963 early and late cut baled hays obtained by C. L. Streeter (unpublished data) were 47.6 and $46.6 \%$, respectively, while the in vitro DMD were 44.2 and $47.6 \%$, respectively. Although the in vivo and in vitro DMD were of the same

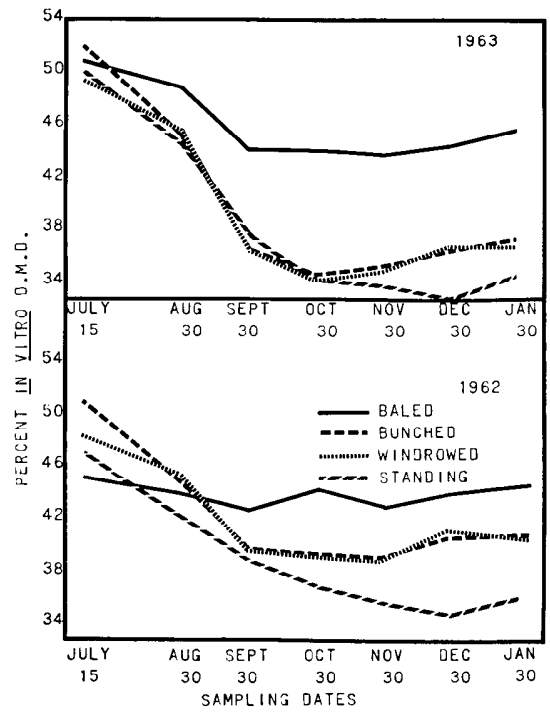

FIG. 2. The relationship of method of storage and storage time on in vitro DMD.

magnitude there was not a difference $(P>.10)$ between the in vivo DMD of the early and late cut hays while the in vitro DMD for the late cut hay was higher $(\mathrm{P}<.05)$ than the in vitro DMD for the early cut hay.

The 1962 in vivo DMD (Streeter, 1964) were lower $(P<.01)$ than in vitro DMD. The in vivo DMD for these hays were 39.5 and $33.4 \%$, respectively, for the early and late cut hay as compared to 48.3 and $44.4 \%$ for the in vitro DMD. It is probable that the animals from which the 1962 in vivo data were obtained were not receiving enough protein without a supplement to meet their requirements, thus, were not fully utilizing the available energy in the forage. This would explain the low in vivo DMD and hence explain the discrepancy between the in vivo and in vitro data.

\section{Literature Cited}

Archibald, J. G., J. Bart, M. L. BlaisDell, and A. F. Spelman. 1951. Quality in roughages. I. Factors which influence hay composition and quality. J. Dairy Sci. 34:656.

Guilbert, H. R., S. W. MEAD, and H. C. Jackson. 1931. Th effect of leaching on the nutritive value of forage plants. Hilgardia. 6-13.

Kamstra, L. D., A. L. Moxon, and O. G. Bentley. 1958. The effect of 
stage of maturity and lignification on the digestion of cellulose in forage plants by rumen microorganisms in vitro. J. Anim. Sci. 17:199-208.

Moxon, A. L., G. Gastler, G. E. Staples, ANd R. M. Jordan. 1951. Grass Hay at its Best: As shown by Chemical analysis and feeding value. S. Dak. Agr. Exp. Stat. Bull. 405.

PRICHARD, G. I., L. P. Folkins, AND W. J. Pigden. 1963. The in vitro digestibility of whole grasses and their parts at progressive stages of maturity. Can. J. Plant Sci. 43:79-87. Streeter, C. L. 1964. The effect of stage of maturity, method of storage and storage time on the nutritive value of Sandhills upland hay. M. S. Thesis, Univ. of Nebraska, Lincoln, p. 26.

Streeter, C. L., D. F. Burzlaff, D. C. Clanton, and L. R. Rittenhouse. 1966. Effect of stage of maturity, method of storage, and storage time on nutritive value of Sandhills upland hay. J. Range Manage. 19:5559.

Tilley, J. M. A., and R. A. Terry. 1963. A two stage technique for the in vitro digestion of forage crops. J. British Grassland Soc. 18:104111.

Watson, S. J., and M. J. Nash. 1960. The conservation of grass and forage crops. Oliver and Boyd, Edinburgh and London, England. 2nd Ed. 